\title{
THE ROLE OF WEAVERS WOMAN IN STRENGTHENING NATIONALISM Case Study in Sajingan Besar Frontier, Indonesia
}

\author{
Elyta $^{1}$ and A. Razak ${ }^{2}$ \\ ${ }^{1}$ Faculty of Social and Political Science, Universitas Tanjungpura, Pontianak, Indonesia \\ ${ }^{2}$ Politeknik Negeri Pontianak. Pontianak, Indonesia \\ E-mail: elyta.elyta79@gmail.com
}

\begin{abstract}
Woven crafts made by women at the Sajingan Besar frontier, besides that it also has economic value, historical value, cultural values that show the identity of the population at the national boundary. The aims of the study were to describe the role of weavers' women in strengthening nationalism, woven is a culture that is typical of the society in Sajingan Besar frontier, Sambas District. There are two data used in this paper, i.e primary data is field studies, and secondary data is literature studies. The result of research shown that there is an important role from weavers' women in Sajingan Besar, namely: (1) Utilization of Natural Resources is to strengthen nationalism by utilizing the availability of natural resources in managing them into woven crafts which are a form of expansion of nationalism because woven crafts are a cultural heritage and has local characteristics of Sajingan Besar, (2) The Role of weavers' women in Sajingan Besar is able to realize a harmonious life with the Malaysian community to strengthen nationalism has become a role model on the frontier whose territory is inhabited by a variety of different tribes, religions and cultures but unity is maintained.
\end{abstract}

Key words: Weavers' Woman; Nationalism; Frontier

\section{PERAN PEREMPUAN PENGANYAM DALAM MEMPERKUAT NASIONALISME Studi di Perbatasan Sajingan Besar, Indonesia}

\begin{abstract}
ABSTRAK. Kerajinan anyaman yang dibuat oleh perempuan-perempuan di perbatasan Sajingan Besar disamping memiliki nilai ekonomis juga memiliki nilai sejarah, nilai budaya yang menunjukkan identitas penduduk di batas negara.Tulisan ini bertujuan untuk mendeskripsikan peran perempuan penganyam dalam memperkuat nasionalisme, anyaman merupakan kebudayaan yang khas masyarakat di perbatasan Sajingan BesarKabupaten Sambas. Data yang digunakan pada tulisan ini berupa data primer melalui studi lapangan, dan data sekunder berupa studi literatur. Penelitian ini menunjukkan bahwa ada peranan penting dari perempuan penganyam Sajingan Besar Melalui: (1) Pemanfaatan Sumber Alam Untuk Memperkuat nasionalisme yaitu dengan memanfaatkan ketersediaan sumber daya alam dengan cara mengelolanya menjadi kerajinan anyaman yang merupakan bentuk perluasan nasionalisme di perbatasan karena kerajinan anyaman adalah kebudayaan warisan leluhur dan memiliki ciri khas lokal Sajingan Besar, (2) Peran Perempuan Penganyam Sajingan Besar dalam mewujudkan kehidupan harmonis dengan masyarakat malaysia untuk memperkuat nasionalisme telah menjadi role model di perbatasan yang wilayahnya didiami berbagai macam suku, agama maupun kebudayaan berbeda namun persatuan dan kesatuan tetap terjaga.
\end{abstract}

Kata kunci: Perempuan Penganyam; Nasionalisme; Perbatasan

\section{INTRODUCTION}

Nationalism consists of political activities that aim to show national identity (Siekmeier 2015, 69). Specifically, national identity is described as the strongest social flow in the 20th century (Bashevkin 2000, 116). Studying about nationalism cannot be separated from the frontier. The area frontier has proven to be the frontline for the sovereignty of the Unitary State of the Republic of Indonesia (Warsilah \& Wardiat 2017, 21). Thus, there has been a paradigm shift that initially underdeveloped areas became the front area. Paradigm changing aims to strengthen sovereignty, the economy and frontier community nationalism. In reality, frontier areas are more vulnerable to foreign influences, which is proven by frontier conditions are presumed to be a general description for other countries to see the condition of a country. Therefore, the frontier area has become an important area regarding development and construction, especially in the context of nationalism.

However, a paradigm shift towards the development of frontier areas is as a manifestation of regional sovereignty has not yet shown significant changes, it means that frontier areas are still inherent in the poverty status (Elyta 2011, 12). This is also supported by reality. It states that rural areas of Indonesia, especially in frontier areas are still concerned with welfare issues (Sutopo 2017, 268). Of course, this welfare problem refers to the issue of poverty which is allegedly able to influence the nationalism of each individual from the frontier community.

Nationalism of each individual society is described by the emergence of awareness to create groups based on the same culture and region to take control of themselves (Guibernau 1996, 47). Communities welfare in a frontier area that is still disadvantages region has an attitude of dependence on neighbouring countries in various ways, one of them is the fulfilment of life needs (Elyta, et al. $2018,312-313)$. This is alleged to be a threat to nationalism on the frontier, where the people's helplessness in fulfilling their daily needs raises a movement of change to support the welfare of society. It cannot be denied that the problem of nationalism is a phenomenon which is directly related to society in the frontier environment.

On the other hand, the Sajingan Besar frontier has economic potential through the development of natural 
resources, such as the development of natural resources by processing pandanus, bamboo and rattan into woven crafts (Razak \& Elyta 2017, 215). Thus, woven crafts are one of the local potentials on the Sajingan Besar Sambas frontier that can be developed massively, both by the local government, and the community engaged in the creative industries. The sources of nationalism problems that are indicated from community economic problems are considered to be overcome through the woven craft.

In fact, making woven is not the main livelihood for the people in Sajingan Besar. The society majority fulfil their daily needs by farming. Woven which is an ancestral inheritance is only used as a side business to obtain additional income and is generally done more by women.

Handwoven crafts produced by weavers in Sajingan Besar have great attractive opportunities in the international market, by elevating Indonesian local culture (Razak \& Elyta 2017, 214). It concluded that there is the increasing interest of foreign and local tourists on waves craft who often visit the Sarawak region, Malaysia.

Indonesia is a multicultural nation consisting of various tribes, religions, groups, and beliefs, these differences should be realized and become reinforcement of nationalism (Sundawa 2017, 203). Therefore, it can be interpreted that weaver's women have an important role in developing the spirit of nationalism by introducing culture to children and future generations, in addition, it is to preserve the ancestral heritage.

The development of nationalism is important to create social cohesion in a country (Maliki 2010, 63). Thus, in addition, it is to have a selling value for peculiarities, weaver's women craft in Sajingan Besar are indicated as media of strengthening community nationalism in the frontier region. Thus, women become important actors in the introduction of nationalism based on the locality in Sajingan Besar. Woven crafts are presumed to be a distinctive culture of the society in the frontier of Sajingan Besar Sambas District. It creates a cultural identity as an Indonesian society, but the nationalism of residents that is lived in the frontier region is often questioned and it gives the impression of weak about nationalism in the communities of frontier Sajingan Besar, Sambas district. This paper aims to analyze the role of weavers' women in strengthening nationalism in the Sajingan Besar frontier, Sambas District.

\section{METHOD}

The research method is a qualitative method. It is the results of research conducted by the author on the frontier of Sajingan Besar, Sambas District. The data are presented in the form of description-analysis based on field data and literature. Researchers analyzed the role of weavers' women in strengthening nationalism through the creation of craft is as a typical society in the frontier of Sajingan Besar, Sambas District. The research was conducted from
February 7, 2018, to October 18, 2018. The informants of this study were the Head of the State Cross-border Post in Sajingan Besar, 4 weavers' women are lived in the frontier area of Sajingan Besar, and 2 public figure in the frontier area of Sajingan Besar. The researcher conducts in-depth interviews and observations to obtain the desired data. The main tool of this research is the researchers themselves are assisted by interview and recorder guidelines from Handphones, the data is obtained processed and analyzed in narrative form, after that the researchers interpret the data to obtain meaning clearer and deeper.

\section{RESULT AND DISCUSSION}

\section{The Role of Weaver Women Sajingan Besar Through Utilization of Natural Resource in Strengthening Nationalism}

Issues are concerning economy and socio-culture are problematic in frontier areas for various reasons, such as the quality and quantity of human resources, regional infrastructure, low productivity of women and the utilization of natural resources that are not optimal (Warsilah \& Wardiat 2017, 33). The connection to the weaver women at the frontier allegedly gave rise to involve themselves in illegal economic activities with the aim of fulfilling daily necessities of life. The poverty that afflicts frontier women also results in the utilization of opportunities to become illegal migrant workers in Malaysia.

Basically, the role is a concept of what can be done by individuals or institutions in society as a social organization (Soekanto 2017, 268). Furthermore, humans, both women and men in social life, have the same status and role (Lotulung \& Mulyana 2018, 139). Based on the researchers' observations, it was seen that the role of making plaits on the Sajingan Besar frontier in Sambas District was women, weaver women on the Sajingan Besar frontier in Sambas District were women who were 30 years old and above. Residents who are still weaving mats, bags, typically believe that the plants they make are inherited from their ancestor's hundreds of years ago. But along with the changes that occur in women, these crafts then have a fairly high selling value. These craft practitioners are mostly from the Sarawak region of Malaysia, while in the Sambas District, this craft is rarely in demand.

The following is the correlation between the role of weavers women in various aspects that strengthen nationalism:

Picture 1 shown that weaver women still preserve the woven fabric which is the ancestral heritage since hundreds of years ago. But along with the changes that occur in social and economic activities at the frontier, woven crafts show selling value to be a solution to the problems of nationalism due to the welfare of the people who are still weak. As woven crafts have attracted 
interested people from the international community, especially from Sarawak Malaysia, while interest in the local area the production of woven crafts is very minimal.

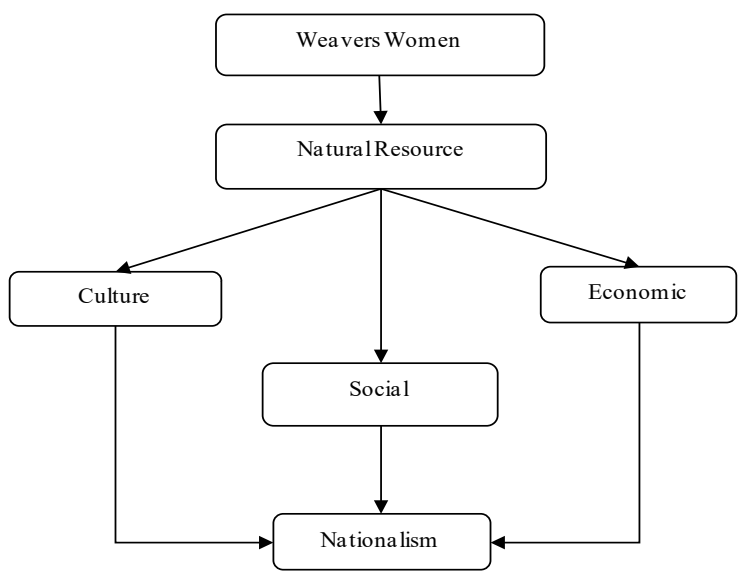

Source: Primer Data, processed 2018

Picture 1. The Role of Weavers Women Through Natural Resources in Various Aspects Strengthening Nationalism

The results of the study also revealed that the price of wicker produced by these weaving women has its own variations according to the accuracy of the model, motif, size and difficulty of the production process. The highest price of one wicker craft measuring $7 \times 10$ feet is sold at a price of Rp. 600,000 , based on policies or intermediary sellers from Sarawak Malaysia. The pricing is based on the high interest and competitive price in the Malaysian market. In other words, if this woven craft continues to be developed and managed well, it certainly can have a positive impact on the economy of the people of Sajingan Besar and automatically lead to a sense of pride in the culture of the Indonesian nation and thus strengthen nationalism.

There are slogans for women who are quite wellknown among frontier communities; namely "even though our stomachs are Malaysian, our hearts remain Indonesia", which means weaver women realize and do not deny the fact that either to make a living or to buy daily necessities is indeed obtained from Malaysia because of easy market access and no cost large, therefore frontier women have bought more thing in Malaysia. From the interviews of researchers with weaver women who found many woven crafts marketed at low prices through collectors to be marketed back in Malaysia, according to informants as well as woven collectors in Sajingan Besar sub-district stated that it was more profitable to sell the wicker to Malaysia than to sell in Indonesia, however, it will not change and their love for Indonesia

While, on the other hand, women who use natural resources by managing it into woven crafts are engaged by Sajingan Besar frontier women still do not master the technology for marketing. It is undeniable that the mastery of technology for marketing today is very important in the modern economy. So that they are only limited to weavers, which are deposited to the container, and they are not market participants. The limited knowledge of women in Sajingan Besar in mastering information technology is caused by several factors including, lack of internet literacy, limited communication technology owned by woven craftsmen, inequality of development from the government and limited signal and internet access in various regions at the Sajingan Besar Sambas frontier. Then, lack of experience in entrepreneurship and the lack of courage of the actors of woven crafts is to innovate. The weaver women of the Sajingan Besar Sambas frontier get lacks information to obtain capital.

The limited access of weaving women in obtaining information related to the new policies imposed by the Bank followed by the difficulty of the process, the stages and the lack of access of women to get loans is one of the difficulties in developing woven crafts. Then, the construction of facilities is still very minimal and is only centred in big cities, causing woven craftsmen is hesitate to develop their businesses because it is difficult to fulfil the required production factors. In addition, road infrastructure that is inadequate or damaged, as well as inadequate transportation equipment, becomes another problem for woven craftsmen to obtain production materials and difficult to distribute their products.

Problems related to labour issues in the frontier region are also focused on the phenomenon of women who become unskilled labourers in oil palm plantations in the Sarawak region of Malaysia. The statement can show that some women become oil workers (Indonesian female workers) in Malaysia. The fact that female workers in the Sajingan Besar frontier area have not been organized to manage local resources in the region. One that inhibits the management of local resources is the determination of border residents to be workers must have a cross-border postcard from the village office, in order to enter Malaysia.

Furthermore, natural resources that are used to fulfil the needs of life are not only by exploiting on a large scale, because it will damage the function of the forest and have a negative impact on the environment. The population in Sajingan Besar uses nature as a necessity of life in a way that has rooted in culture, is still traditional and takes care of the sustainability of nature. They took the basic woven ingredients from bamboo, rattan and pandanus to make woven crafts that had selling value, but they also did not forget to replant bamboo, rattan and pandanus to maintain a natural balance.

While to meet household consumption needs, residents in Sajingan Besar still use traditional methods by utilizing nature, such as fishing with simple fishing gear such as fishing rods, trawls, or nets. Then, the community also uses vacant land for gardening and the results for household consumption are not for sale. The natural potential in agriculture and plantations is the land available for cultivation and has relatively good fertility. 
International trade in the form of export and import activities has occurred in the frontier region (Elyta 2017, 59). It is evidenced by the existence of inter-state trade cooperation between Indonesia and Malaysia conducted at the Cross-frontier State Post, Sajingan Besar where women boost the economy, it means that local women take advantage of opportunities to open businesses in order to improve the household economy. Women who were oriented to household needs developed into a market opportunity. The garden products in the form of vegetables and spices, they had were then sold to agents in Sarawak Malaysia. Later, woven crafts that had only been used for domestic use turned into a fairly high market selling value in Malaysia.

Although basically the main economic resources of the people in the Sajingan Besar frontier region come from the agricultural sector, the existence of weaver women as creative industries has created new opportunities and is targeted by the Malaysian market. Based on Sambas Regency Central Bureau of Statistics data, there are two active woven industry businesses since 2008 to the present (Sambas in the Central Bureau of Statistics (Razak \& Elyta 2017, 215). The creative woven industry business in Sajingan Besar accommodate local weaving women. However, the constraints faced are limited knowledge of marketing of local residents so that the production of woven crafts is sold with relatively cheap prices using ringgit. This is due to the weak bargaining position of handicrafts produced to be marketed globally.

Another obstacle is the still difficult access road and the location of some remote villages in Sajingan Besar, which compared to Sarawak Malaysia is somewhat left behind. This is also one of the factors that have not yet advanced the woven crafts industry in Sajingan Besar. While the woven craft comes from Sajingan Besar has been marketed in the international market by entrepreneurs from Sarawak, Malaysia.

The construction of facilities and infrastructure, human resources until the management of the resulting webbing can be a force that supports woven crafts. It is to be marketed in international markets without having intermediaries at discounted prices so that it can help the economy of frontier communities and create a sense of pride in national culture. The results of the study also found that the economy of the population in Sajingan Besar was influenced by the economy of women in the Sarawak frontier region, Malaysia. Women in Sajingan Besar use two currencies, namely Rupiah and Ringgit. In daily transactions, local women often use Ringgit, because they buy more goods from neighbouring countries. This also affects the economy of women in the Sajingan Besar frontier, which is more oriented to the Ringgit because the exchange rate of Ringgit is greater than the Rupiah.

In addition, the attitude of tribal sentiments and religion is rarely heard in this region because the people have had the spirit of nationalism by working together to preserve the sovereignty of the Indonesian people and improve their welfare through woven crafts. For this reason, the role of weaver women is very important to develop and expand nationalism through the culture and creative industries of woven crafts, where weaver women have acted as the front guard in introducing, delivering, socializing, and strengthening nationalism in the national frontier. It is not only in the family sphere but also in the international community, especially in Sarawak, Malaysia. Woven handicrafts that are used as an economic value product are one of the cultures in Sajingan Besar, through woven crafts also women woven crafts support the local economy as well as nationalism by preserving local culture, namely woven crafts.

\section{The Role of Weavers Women Sajingan Besar in Realizing Harmonious Life with Malaysian Commu- nities to Strengthen Nationalism}

Women empowering is through education while providing political rights (Thomas 2004, 212). In this case, weaverwomen becomeactors of nationalism reinforcement at Sajingan Besar frontier through woven crafts, frontier women have given the influences on nationalism, the role of exploring nationalism or strengthening the sense of frontier nationalism is empowered through education. It is done by providing strength in the form of expanding insight and mindset creative and economical for weaving women to manage weavers into an economic value is woven handicraft product that fosters pride, ownership of local and national special works. One effort that is quite effective in exploring and growing nationalism can be done by applying education in the field of entrepreneurship empowered to weaving women.

Culture and ancestry are used as tools to foster nationalism. Although later nationalists will emerge who create classes, especially for women namely middleclass women and workers (Rosenberg 2010, 52). Woven handicrafts in Sajingan Besar are one of the manifestations of their ancestral heritage in the past. Through the plaits of their ancestors, they show their thoughts, expressed feelings to respond to every historical event in the area where they lived. The woven craft is a historical witness about the civilization of women in Sajingan Besar.

Promoting culture and fostering awareness is the attitude of nationalism (Thomas 2004, 213), the existence of the nation is inseparable from the existence of culture created and guarded by a human, it is by elevating cultural values in terms of management, promotion and marketing is a symbol based on nationalism. Various cultural symbols are manifested as human expressions in conveying their personal meanings that are different from others (Tampubolon \& Darmawan 2016, 22-23). These values are presented in various patterns of attitudes, knowledge and results of creativity that produce cultural products. It includes woven crafts as a product of the creativity of Sajingan Besar women, which is also a cultural 
representation of the region. In showing this phenomenon, the picture attachments are as follows:

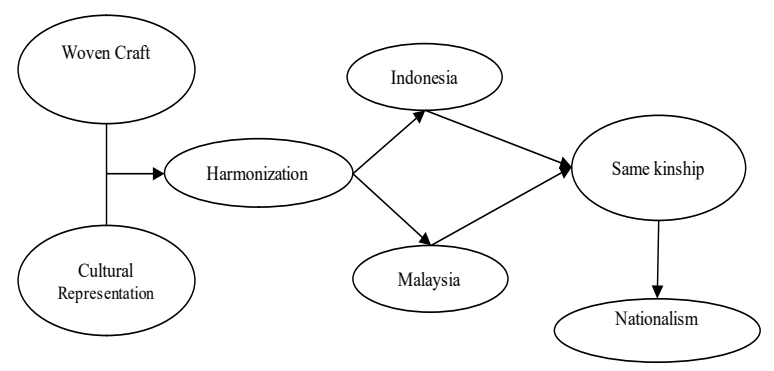

Source: Primer Data, processed 2018

Figure 2. The Role of Weavers Women in Sajingan Besar Indonesia in realizing Harmonious Life with Malaysian Society

Figure 2 can be explained that weaving contains the value of art which has an important meaning as the adhesive of women's unity in Sajingan Besar. Women are consisting of various tribes and also religions live side by side in Sajingan Besar. There are Dayaks, Sambas Malay tribes, Javanese, and Batak tribes, they also become woven craftsmen such as bags and mats. However, more Dayaks and Malay tribes are weaving this craft. Then, the religion found in the Sajingan Besar is Catholicism, Protestantism and Islam. Tribal and religious communities in this region live harmoniously and embrace together with help. This means that women can be empowered and empower themselves through woven crafts. Women can expand and strengthen nationalism while remaining united despite having differences, in other words, that the existence of multiculturalism in the group of weaving women from various customs and cultures is together in producing woven crafts that they wicker.

Next is the individual rational achievement as rationally which is a way of maintaining the unity of oneself from the potential multi or the pressure of structure, it is also a symbol of the social membership of a particular group (Williams 2000, 321). There are women craftsmen who are craftsmen in fixed industrial centres and some are home-made craftsmen, whose results sell in fixed industries or directly to collectors in Sarawak, Malaysia.

Nationalism awareness reflects identity and character that is able to respect the existence of other communities, respect rationality and have a strong moral awareness (Poespowardojo 2003, 4). The craft itself has a meaning for women in Sajingan Besar to attach harmony between indigenous communities in Sajingan Besar, including indigenous Dayak communities, indigenous Malay communities and other tribes who also live on the frontier. It is not only establishing good relations between communities within the country, but also the frontier women of Sajingan Besar. They also have close and good relations with the Dayak and Malay communities in the Sarawak Malaysia.

Women in Sajingan Besar believe that the philosophy of life loves each other which has been embedded since the time of their ancestors. Then caring and tolerance value becomes a way of life for women and is taught to their future generations. Woven crafts that exist today show that women in Sajingan Besar who have different cultures, races and religions are able to live in harmony and coexist well.

The craft which is the local wisdom of Sajingan Besar women is a persuasive medium in interpreting differences and diversity, it gives the positive impact, example there are rarely divisions and conflicts between women in the region. Learning from past history in Sambas District which was once the centre of ethnic conflict in 1998, women have become increasingly able to be wise in addressing issues such as differences in women aspect.

An understanding of feminists which was initially ignored by historians has been increasingly influential since the 19th century (Chatterjee in (Rosenberg 2010, 49), one of the active roles of border weaving women who socialize with residents in Sarawak Malaysia, making woven crafts is not only done by people in Sajingan Besar. Many people in Sarawak also make woven crafts for their household needs. Because the population of Sajingan Besar, Indonesia has many relatives or families who have lived in Sarawak Malaysia, so they often go back and forth to visit their families in Malaysia. This means that between the population of Sajingan Besar and residents in the Sarawak region have a strong bond of brotherhood. Life at the national frontier is not a problem for them to love Indonesia, maintain their culture and nationalism but it becomes an advantage and pride for weaving women to show their existence. The role of women in expanding nationalism need not be doubted even though they are in frontier areas and vulnerable to foreign influences. There are mosques and church in one village, they remain harmonious, respect each other and have a high sense of tolerance. Differences are necessities that should be managed so that the differences become a media of unification and not division. The development of nationalism and the love of the homeland has begun since the Indonesian nation fought for independence until now weaver women also fight for their nationalism by continuing to preserve the woven craft culture based on national unity and integrity both in political, social, cultural, economic and national tenacity and security aspects Indonesia.

\section{CONCLUSION}

The role of Sajingan weavers' women in utilizing natural resources has strengthened nationalism by preserving economically valuable cultures, namely woven crafts. The existence of frontier weaving women plays an important role considering the low welfare of frontier communities and conditions that are synonymous with the word 'lagging' which means that they do not have the modern infrastructure to support the fulfilment of daily 
needs so that it influences social behaviour patterns and thinking. They are vulnerable to exploitation. Indonesian Workers (TKI) illegally go to Malaysia at low wages.

The role in strengthening nationalism has been realized through the independence of weaver women, so it is to strengthen frontier nationalism. The differences in ethnicity, language, religion and culture at the Sajingan Besar frontier describe the unity of the Indonesian society to Malaysian society through the role of preserving the culture of woven crafts together, so that people feel proud to be part of Indonesia, upholding the values of unity and nationalism. Weavers women also become role models. How difficult it is for women's lives at the national frontier, they still love the homeland and do not leave the ancestral cultural heritage by preserving it into a variety of creativity and high cultural awareness.

\section{REFERENCES}

Bashevkin. (2000). In the shadow of free trade: Nationalism, feminism and identity politics in contemporary English. Sylvia Journal of Canadian Studies, 35, (2), 109-204. http://doi/abs/10.3138/ jcs.35.2.109

Elyta. (2011). Penanganan Ancaman Keamanan Manusia: Penanganan Keterbelakangan Pembangunan Melalui Pembangunan Perkebunan Kelapa Sawit di Wilayah Perbatasan. Pontianak: Bulan Sabit Press.

Elyta. (2017). Perdagangan Gula Ilegal di Wilayah Perbatasan Entikong Indonesia Dan Malaysia. Sosiohumaniora, 19, (1), 59-63.

Elyta, Sofyan, A. Rahman, I. \& Nuzulian, U. (2018). Nasionalisme Masyarakat Perbatasan di Kalimantan Barat Indonesia. MANDALA Jurnal Hubungan Internasional, 1, (2), 311-322.

Guibernau, M. (1996). Nationalisms: the nation-state and nationalism in the twentieth century. UK: Cambridge University Press.

Lotulung, L.J.H. \& Mulyana, D. (2018). Perempuan Dalam Politik di Sulawesi Utara. Sosiohumaniora, 20, (2). 138-144.
Maliki, Z. (2010). Sosiologi Politik: Makna Kekuasaan dan Transformasi Politik. Yogyakarta: Universitas Gadjah Mada Press.

Poespowardojo, S. (2003). Dinamika dan Impikasi Etis Wawasan Kebangsaan dalam Mengnyongsong Hri Depan Indonesia. Jurnal Ketahanan Nasional, $8,(2), 1-6$.

Razak, \& Elyta. (2017). Faktor Penghambat Kerajinan Anyaman Tangan di perbatasan Sajingan Besar dalam Menghadapi Masyarakat Ekonomi Asean. Sosiohumaniora, 19, (3), 213-217.

Rosenberg, L. (2010). The new woman and 'the dusky strand: the place of feminism and women's literature in early Jamaican nationalism. Feminist Review, 95, 46-63.

Siekmeier, J. (2015). Nationalism and Globalization in Latin America. Current History, 114, (769), 68-72.

Soekanto, Soerjono. (2017). Sosiologi Suatu Pengantar. Jakarta: Rajawali Pers.

Sundawa, D. (2017). Penguatan Karakter Mahasiswa yang Berwawasan Kebangsaan dalam Menghadapi Tantangan Disintegrasi Bangsa. Seminar Nasional Tahunan, 1, (1), 202-205.

Sutopo, D.S. (2017). Kemiskinan di Perdesaan Dalam Tinjauan Morfologi Sosial (Studi Kasus Kemiskinan di Desa Sumber Salak Kecamatan Curahdami Kabupaten Bondowoso Jawa Timur). Sosiohumaniora, 19,(3), 268-273.

Tampubolon, A, \& Darmawan, C. (2016). Fashion Budaya Nasional dalam Konteks Wawasan Kebangsaan: Studi Kasus pada Jember Fashion Carnaval. Journal of Urban Society's Art, 3, (1), 19-26.

Thomas, D A. (2004). Modern Blackness: Nationalism, Globalization and the Politics of Culture in Jamaica. Durham: Duke University Press.

Warsilah, H, \& Wardiat, D. (2017). Pembangunan Sosial di Wilayah Perbatasan Kapuas Hulu Kalimantan Barat. Jakarta: Yayasan Obor Indonesia.

Williams, R. (2000). Making Identity Matter: Identity Society and Social Interaction. Durham: sociologypress. 